\title{
IN VITRO ANTIOXIDANT ACTIVITIES OF SALAZINIC ACID AND ITS DERIVATIVE HEXAACETYL SALAZINIC ACID
}

\author{
G. Selvaraj ${ }^{1}$, A. Tinabaye $^{2}$, R. Ananthi ${ }^{3}$ \\ ${ }^{1}$ Research scholar,Department of Chemistry, Kanchi Mamunivar Centre for Post Graduate Studies, Lawspet, \\ Puducherry, India. \\ ${ }^{2}$ Associate professor,Department of Chemistry, Kanchi Mamunivar Centre for Post Graduate Studies, Lawspet, \\ Puducherry, India. \\ ${ }^{3}$ Research scholar,Department of Chemistry, Kanchi Mamunivar Centre for Post Graduate Studies, Lawspet, \\ Puducherry, India.
}

\begin{abstract}
The stress generated upon oxidation can lead to the production of free radicals which may cause many degenerative diseases. In order to eliminate the free radicals antioxidants have been used. The present study was to estimate the antioxidant activity of salazinic acid and its derivative hexaacetyl salazinic acid. The antioxidant property were studied under the categories DPPH, FRAP, Metal chelating activity, Hydroxyl scavenging activity, Lipid peroxidation activity, Phosphomolybdenum activity, Superoxide dismutase activity. We have isolated salazinic acid from the lichen Parmotrema reticulatum collected from Kodaikanal hills. The Derivative hexaacetyl salazinic acid was also prepared. Both the compounds were subjected to determine the in vitro antioxidant activity and their $I C_{50}$ value are also calculated. The Lichen metabolite and its derivative have shown better antioxidant efficiency.
\end{abstract}

Keywords: Oxidative stress, Salazinic acid, Hexaacetyl salazinic acid, Tannic acid. $* * *$

\section{INTRODUCTION}

Lichens are Unique symbiotic association of algae and fungi can produce a bioactive compounds such as depsides, depsidones, dibenzofurans having antifungal, anticancerous, antinflammatory activities as an immunomodulator[1]. The body metabolic processes can triggers the production of several free radicals such as $\mathrm{OH}^{-}, \mathrm{O}^{2-}, \mathrm{H}_{2} \mathrm{O}_{2}$ radicals which can cause damage to the cell growth, can able to arise several health disorders such as cancer, neurological ailments, arthritis and so on. The antioxidants are very essential to eliminate the effective action of free radicals and protect us from various degenerative diseases[2,3]. Recently, more importance was given for the natural antioxidants. In this we have studied the antioxidant potential of Salazinic acid and Hexaacetyl Salazinic acid.

\section{MATERIAL AND METHODS}

\subsection{Collection and Identification of Lichen Material}

The lichen Parmotrema reticulatum (Taylor) M. Choisy was collected from Kodaikanal hills, 7000ft, Dindigul district in Tamil Nadu (South India). It was botanically identified by Dr. K. P. Singh, Botanical Survey of India, Allahabad.

\subsection{Botanical Information}

Phylum : Lichens

Class : Lecanoromycetes

Order : Lecanorales

Family : Parmeliacea
Genus : Parmotrema

Species : Parmotrema reticulatum

Habit : Foliose type

\subsection{Preparation of Lichens Extracts}

\subsubsection{Acetone Extraction:}

The air-dried lichen $(125 \mathrm{~g})$ was extracted with hot acetone (1L, each time) till the last extract was almost colourless (four extraction). The combined acetone extract was concentrated under vacuum using a rotatory evaporator which yields a pale yellow pasty mass $(5 \mathrm{~g})$. This was found to be heterogeneous by TLC examinations. The pasty mass was subjected to separation by column chromatography with silica gel (Merck) built in benzene. The fraction benzeneethyl acetate (40:60) yield colourless solid.

\subsubsection{Identification of Lichen Acids:}

To identify the lichen metabolite via TLC. The compound were then spotted on thin layer chromatography (TLC) plates (silica gel, Merck) and run in solvent system (170:30 toulene/glacial acetic acid). Subsequently, each TLC plate was then sprayed with $10 \%$ sulfuric acid and heated at $110^{\circ} \mathrm{C}$ for 10 minutes to visualize the lichen compound. 
<smiles>Cc1cc(O)c(C=O)c2c1C(=O)Oc1c(CO)c(O)c3c(c1O2)C(O)OC3=O</smiles>

Fig:1. Salazinic acid

Salazinic acid (Fig.1) obtained as colourless needles, m.pt. 260-268 ${ }^{\circ} \mathrm{C}$ (with decomposition) with change in colour to brown at $240^{\circ}$. It forms red colour solution with $\mathrm{FeCl}_{3}$. It gives red crystals of potassium salt when added to hot potassium carbonate. It gives red colour with $\mathrm{KOH}$. The molecular formula $\mathrm{C}_{18} \mathrm{H}_{12} \mathrm{O}_{10}$. The structure was confirmed with spectral data.

\subsubsection{Acetylation of Salazinic Acid:}

A compound $(0.1 \mathrm{~g})$ was suspended in acetic anhydride $(1 \mathrm{ml})$ and perchloric acid (60\% 1drop) were added. The mixture was kept at room temperature for 2 hours and then poured into ice-water. The acetate soon solidified to a colorless crystalline solid. It was filtered off and crystallized from ethyl alcohol when it separated as long colorless prismatic rods. On heating it lost the solvent of crystallization at $150^{\circ} \mathrm{C}$ and then melted at $177-178^{\circ} \mathrm{C}$. The compound hexaacetyl salazinic acid(Fig.2) was confirmed with spectral data. The molecular formula of hexaacetyl salazinic acid is $\mathrm{C}_{30} \mathrm{H}_{26} \mathrm{O}_{17}$.<smiles>COC(C)=O</smiles>

Fig:2 Hexaacetyl salazinic acid

\section{MATERIALS AND METHODS}

\subsection{DPPH Radical Scavenging Assay}

The antioxidant ability of a compound is depends upon its hydrogen donating or radical scavenging ability by using the stable radical DPPH. According to the method of Blois (1958)[4]. In this method, the volume was adjusted to $100 \mu 1$ with methanol and sample at various concentration (100-
$500 \mu \mathrm{g})$. The standard $(0.1 \mathrm{mM}$ concentration methanolic solution of DPPH was allowed to stand for $20 \mathrm{~min}$ at $27^{\circ} \mathrm{C}$. The sample absorbance were measured at $517 \mathrm{~nm}$. The $\%$ of radical scavenging activity of the sample can be determined by using:

$\% \mathrm{DPPH}$ radical scavenging activity = (Control ODSample OD/ control OD)x 100

The analysis was performed in triplicate. The sample concentration providing $50 \%$ inhibition $\left(\mathrm{IC}_{50}\right)$ under the assay condition was calculated from the graph of inhibition percentage against sample concentration.

\subsection{Hydroxyl Radical Scavenging Activity:}

The method of Hydroxyl radical scavenging activity of the sample was put-forward by Klein et al. (1991)[5]. In this method, sample taken at different concentrations (100$500 \mu \mathrm{g})$ were added with $1 \mathrm{~mL}$ of Fe-EDTA solution $(0.13 \%$ ferrous ammonium sulfate and $0.26 \%$ EDTA), $0.5 \mathrm{ml}$ of EDTA solution $(0.018 \%)$, and $1 \mathrm{~mL}$ of dimethyl sulfoxide (DMSO) $(0.85 \% \mathrm{v} / \mathrm{v}$ in $0.1 \mathrm{M}$ phosphate buffer, $\mathrm{pH} 7.4)$. The reaction was initiated by adding $0.5 \mathrm{~mL}$ of ascorbic acid $(0.22 \%)$ and incubated at $80-90^{\circ} \mathrm{C}$ for $15 \mathrm{~min}$ in a water bath. After the period of incubation by the addition of $1 \mathrm{~mL}$ of ice cold TCA. The reaction was terminated. Nash reagent (75.0g of ammonium acetate, $3 \mathrm{ml}$ of glacial acetic acid, and $2 \mathrm{~mL}$ of acetyl acetone were mixed and raised to $1 \mathrm{~L}$ with distilled water) was added and left at room temperature for $15 \mathrm{~min}$. the intensity of the colour should be measured at $412 \mathrm{~nm}$ against reagent blank. The \% radical scavenging activity of the sample were calculated as follows:

$\%$ Hydroxyl radical scavenging activity $=($ Control ODSample OD/ Control OD) x 100

The analysis was performed in triplicate. The sample concentration providing $50 \%$ inhibition $\left(\mathrm{IC}_{50}\right)$ under the assay condition was calculated from the graph of inhibition percentage against sample concentration

\subsection{Superoxide Radical Scavenging Activity:}

The superoxide radical scavenging activity of the sample was determined in terms of Beauchamp and Fridovich 1971[6] to inhibit formation by scavenging the superoxide radicals generated in riboflavin-light-NBT system. Each $3 \mathrm{~mL}$ reaction mixture contained $50 \mathrm{mM}$ sodium phosphate buffer ( $\mathrm{pH} 7.6$ ), 20mg riboflavin, $12 \mathrm{mM}$ EDTA, $0.1 \mathrm{mg}$ NBT and various concentrations $(100-500 \mu \mathrm{g})$ of sample. The absorbance was measured at $590 \mathrm{~nm}$. Immediately after illumination of reaction mixture with sample extract 90 seconds. The entire reaction should be carried out in box timed with aluminium foil. Identical tubes with reaction mixture kept in dark served as blank. The percentage inhibition of superoxide anion generation was calculated as:

$\%$ Superoxide radical scavenging activity $=($ Control ODSample OD/ Control OD) x 100 
The analysis was performed in triplicate. The sample concentration providing $50 \%$ inhibition $\left(\mathrm{IC}_{50}\right)$ under the assay condition was calculated from the graph of inhibition percentage against sample concentration.

\subsection{Ferric Reducing Antioxidant Power (FRAP)}

\section{Assay:}

The reducing capacity of the sample was estimated by using FRAP assay by Benzie and Strain, 1996[7]. The FRAP reagent contained $2.5 \mathrm{~mL}$ of a $10 \mathrm{mM}$ TPTZ solution in $40 \mathrm{mM} \mathrm{HCl}, 2.5 \mathrm{~mL}$ of $20 \mathrm{mM} \mathrm{FeCl} 3 \cdot 6 \mathrm{H}_{2} \mathrm{O}$ and $25 \mathrm{~mL}$ of $300 \mathrm{mM}$ acetate buffer ( $\mathrm{pH} 3.6)$. It was freshly prepared and warmed at $37^{\circ} \mathrm{C} .900 \mu \mathrm{L}$ FRAP reagent was mixed with $90 \mu \mathrm{l}$ water and $10 \mu \mathrm{l}$ of the sample. The reaction mixture was incubated at $37^{\circ} \mathrm{C}$ for 30 minutes and the absorbance was measured at $593 \mathrm{~nm}$.

\subsection{Metal Chelating Assay}

Ability of sample to form chelation with $\mathrm{Fe}^{+2}$ ions was estimated by the method Dinis et al. (1994)[8]. Briefly, 50 $\mu$ l of $2 \mathrm{mM} \mathrm{FeCl}_{2}$ was added to $1 \mathrm{~mL}$ of the sample $(250 \mu \mathrm{g})$. The reaction was initiated by the addition of $0.2 \mathrm{~mL}$ of $5 \mathrm{mM}$ ferrozine solution. The mixture was shaken thoroughly and allowed to stand at room temperature for $10 \mathrm{~min}$. The absorbance of the solution was measured spectroscopically at $562 \mathrm{~nm}$. The analysis was performed in triplicate and the results were expressed as EDTA equivalent.

\subsection{Phosphomolybdenum Assay:}

For phosphomolybdenum assay a modified procedure by Prieto et al.(1999)[9]. The antioxidant activity of the sample can be evaluated. An aliquot of $0.1 \mathrm{~mL}$ of sample solution was combined in a $4 \mathrm{~mL}$ vial with $1 \mathrm{~mL}$ of reagent solution ( $0.6 \mathrm{M}$ sulphuric acid, $28 \mathrm{mM}$ sodium phosphate and $4 \mathrm{mM}$ ammonium molybdate). The vials were capped and incubated in a water bath at $95^{\circ} \mathrm{C}$ for $90 \mathrm{~min}$. After the samples had cooled to room temperature, the absorbance of the mixture was measured at $765 \mathrm{~nm}$ against a blank. The result reported are mean values expressed as milligrams of ascorbic acid equivalents per gram sample.

\subsection{Lipid Peroxidation Inhibiting Assay:}

The inhibition ability of the sample against lipid peroxidation was carried out by using modified procedure of Ohkawa et al. (1979)[10]. According to the method, the goat liver was washed vigorously in cold phosphate buffer saline $(\mathrm{pH}$ 7.4) and homogenized to form $10 \%$ homogenate. Then filter the homogenate and centrifuged at $1000 \mathrm{rpm}$ for $10 \mathrm{~min}$ and the supernatant used to carry out the assay. To $0.5 \mathrm{~mL}$ of $10 \%$ homogenate, $0.5 \mathrm{~mL}$ of the sample $(50-250 \mu \mathrm{g})$ was added. To this, $0.05 \mathrm{~mL}$ of $0.07 \mathrm{M}$ ferrous sulphate was added and incubated at room temperature for $30 \mathrm{~min}$. To the incubated solution, $1.5 \mathrm{~mL}$ of $20 \%$ acetic acid (pH 3.5) and $1.5 \mathrm{~mL}$ of $0.8 \%$ TCA (in $1 \% \mathrm{SDS}$ ) were added. The tubes were incubated at $100^{\circ} \mathrm{C}$ for 1 hour and cooled to room temperature. About $5 \mathrm{~mL}$ of butanol was added and centrifuged at $3000 \mathrm{rpm}$ for 10min. The upper layer was used to read the absorbance at $532 \mathrm{~nm}$. The percentage inhibition was calculated as follows:

$\%$ inhibition $=[($ Control OD-Sample OD $) /$ Control OD $] \mathrm{x}$ 100

The analysis was performed in triplicate. The sample concentration providing $50 \%$ inhibition $\left(\mathrm{IC}_{50}\right)$ under the assay condition was calculated from the graph of inhibition percentage against sample concentration.

\section{STATISTICAL ANALYSIS}

All assays were carried out in triplicates and result are expressed as mean \pm SD. Data were analyzed in Microsoft EXCEL-2010 by taking triplicates and thus mean and Standard Deviation (SD) obtained.

\section{RESULT AND DISCUSSION}

Antioxidant capacity is widely used as a parameter for medicinal bioactive components. Radical scavenging activities are very important due to the deleterious role of free radicals in food and in biological systems. Diverse method are currently used to assess the antioxidant activity of Natural bioactive compounds. In our study, we have analyzed the antioxidant activity of Salazinic acid and hexaaceytyl salazinic acid.

\subsection{Free Radical Scavenging by DPPH:}

For the assessment of free radical scavenging activity of photomedicine stable DPPH radical has been used. The DPPH radical scavenging activity of the two test compounds salazinic acid and its derivatives hexaacetyl salazinic acid were evaluated at different concentration $(100-500 \mu \mathrm{g} / \mathrm{mL})$. The result were given in the Table: 1 . The dose dependent activity of the two test compounds and the standard were expressed in Chart: 1 and Chart: 2 . The \% inhibition activity of the test compound were also determined and are compared with the standard Tannic acid. However, the result shows lesser \% inhibition than the standard tannic acid. The test compound shows significant DPPH radical scavenging activity because the test compounds are naturally obtained and are free from side effect. It is established that the derivative hexaacetyl salazinic acid shows higher \% inhibition and lower $\mathrm{IC}_{50}$ value than salazinic acid. 


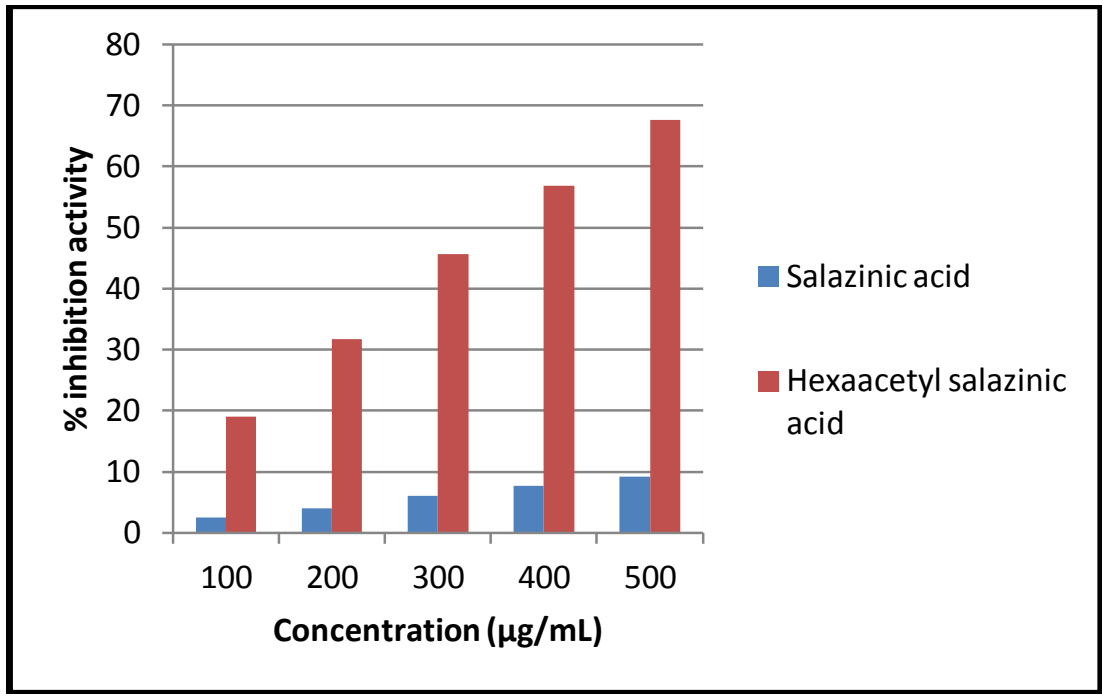

Chart: 1-DPPH Free Radical Seavenging Activity of Salazinic acid and Hexaacetyl salazinc acid

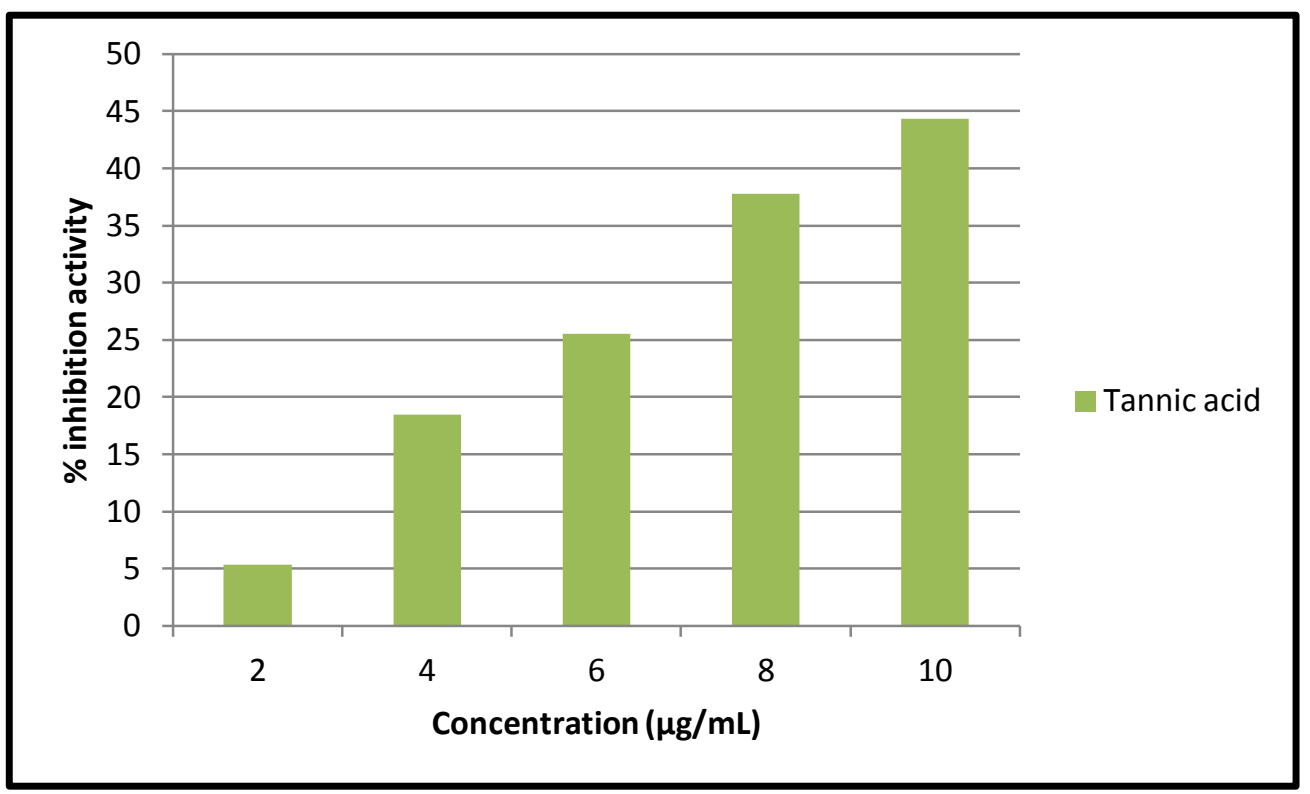

Chart: 2-DPPH Free Radical Scavenging Activity of Tannic acid

Table: 1-DPPH Free Radical Scavenging Activity

\begin{tabular}{|l|l|l|l|}
\hline $\begin{array}{l}\text { Test } \\
\text { compound }\end{array}$ & $\begin{array}{l}\text { Concentratio } \\
\mathrm{n}(\mu \mathrm{g} / \mathrm{mL})\end{array}$ & \% Activity & $\mathrm{IC}_{50}(\mu \mathrm{g} / \mathrm{ml})$ \\
\hline & 100 & $2.45 \pm 0.20$ & \\
Salazinic acid & 200 & $3.99 \pm 0.20$ & \\
& 300 & $6.08 \pm 0.10$ & $974.66 \pm 30.69$ \\
& 400 & $7.72 \pm 0.20$ & \\
& 500 & $9.22 \pm 0.20$ & \\
\hline & 100 & $19.04 \pm 1.13$ & \\
Hexaacetyl & 200 & $31.73 \pm 2.17$ & \\
salazinic acid & 300 & $45.70 \pm 1.31$ & $127.78 \pm 2.76$ \\
& 400 & $56.89 \pm 1.03$ & \\
& 500 & $67.58 \pm 0.69$ & \\
\hline & 2 & $5.31 \pm 0.54$ & \\
Tannic acid & 4 & $18.45 \pm 0.17$ & \\
& 6 & $25.50 \pm 0.38$ & $4.31 \pm 0.02$ \\
& 10 & $37.78 \pm 0.38$ & \\
& & $44.31 \pm 0.22$ & \\
\hline
\end{tabular}




\subsection{Hydroxyl Radical Scavenging Activity:}

Among all the reactive oxygen species, the hydroxyl radical was the major active oxygen species which causes lipid peroxidation and several biological disorders. The Hydroxyl radical scavenging activity of the two test compounds salazinic acid and hexaacetyl salazinic acid were determined at different concentration $(100-500 \mu \mathrm{g} / \mathrm{mL})$. The $\mathrm{IC}_{50}$ values of the test compounds were also determined. The results were given in the Table: 2 . The dose dependent activity of the two test compounds and the standard were expressed in Chart: 3 and Chart: 4. From the results, it has been found that both the test compounds shows nearly similar hydroxyl radical scavenging activity and also possess lesser activity than the standard Tannic acid.

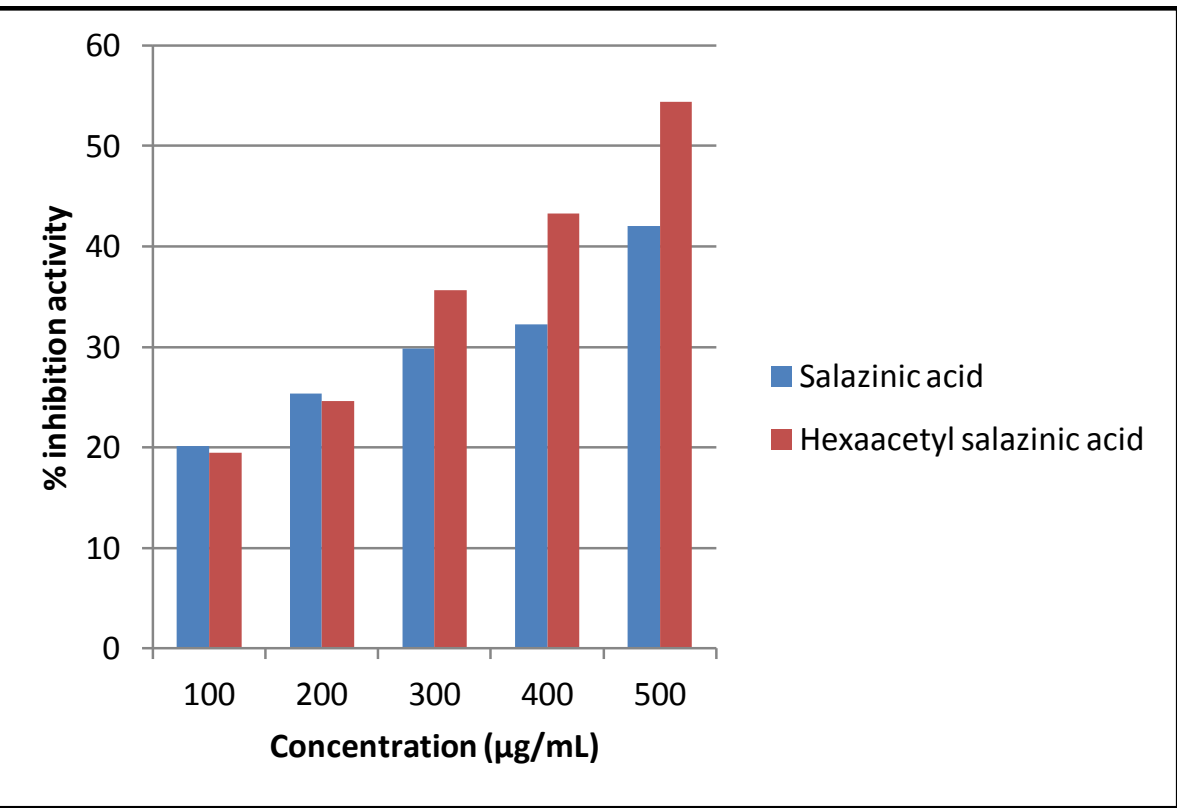

Chart: 3-Hydroxyl Radical Scavenging Activity of Salazinic acid and Hexaacetyl salazinic acid

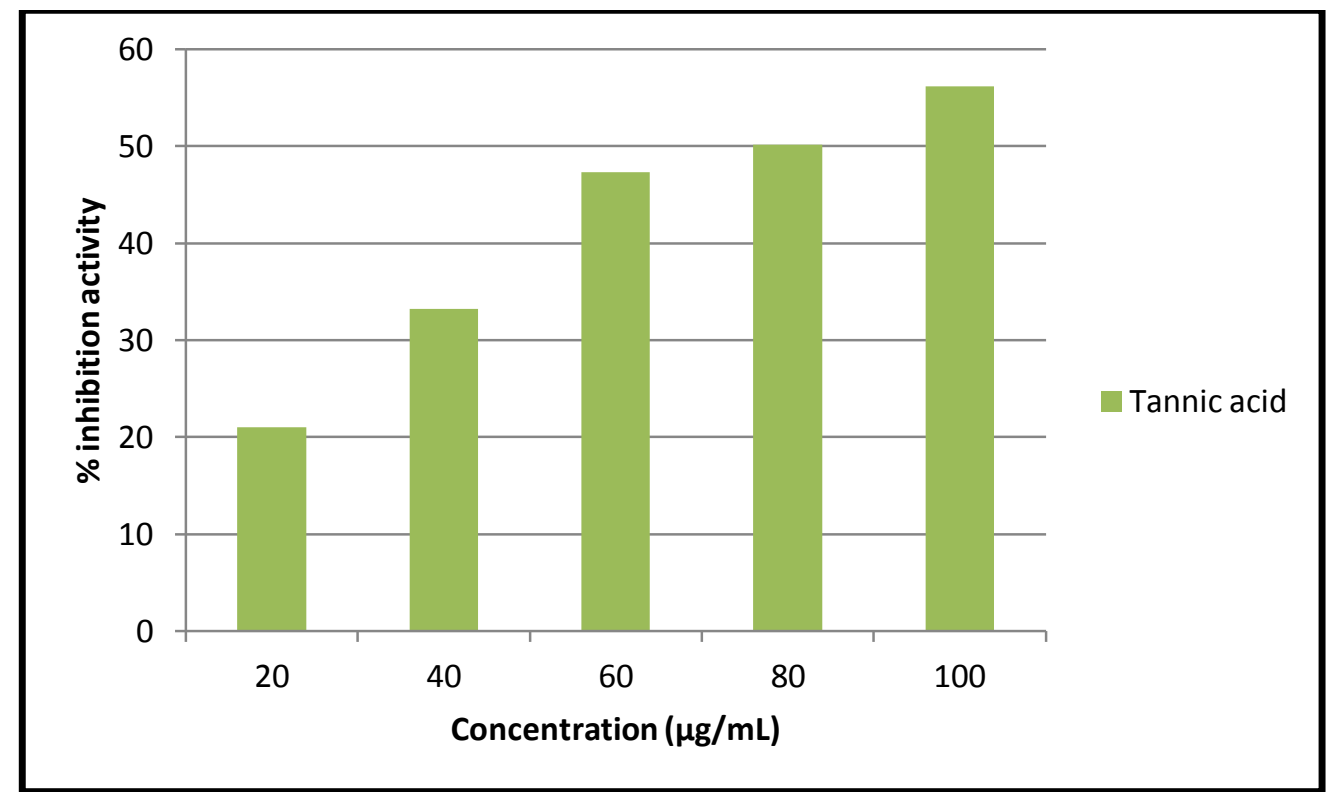

Chart: 4-Hydroxyl Radical Scavenging of Tannic acid 
Table: 2-Hydroxyl Radical Scavenging Activity

\begin{tabular}{|l|l|l|l|}
\hline Test compound & $\begin{array}{l}\text { Concentration } \\
(\mu \mathrm{g} / \mathrm{mL})\end{array}$ & \% Activity & $\mathrm{IC}_{50}(\mu \mathrm{g} / \mathrm{ml})$ \\
\hline & 100 & $20.15 \pm 0.07$ & \\
& 200 & $25.38 \pm 0.30$ & \\
Salazinic acid & 300 & $29.83 \pm 0.39$ & $193.36 \pm 0.12$ \\
& 400 & $37.27 \pm 0.52$ & \\
& 500 & $42.02 \pm 0.65$ & \\
& & $19.46 \pm 0.47$ & \\
& 100 & $24.60 \pm 0.61$ & \\
Hexaacetyl & 200 & $35.62 \pm 1.10$ & $161.87 \pm 1.67$ \\
salazinic acid & 300 & $43.28 \pm 0.15$ & \\
& 400 & $54.39 \pm 0.40$ & \\
\hline & 500 & $21.06 \pm 0.52$ & \\
Tannic acid & 20 & $33.18 \pm 0.00$ & \multirow{2}{*}{$51.51 \pm 0.19$} \\
& 40 & $47.35 \pm 0.52$ & \\
& 80 & $50.15 \pm 0.92$ & \\
& 100 & $56.14 \pm 0.79$ & \\
\hline
\end{tabular}

\subsection{Superoxide Radical Scavenging Activity}

Superoxide radical plays a pivotal role in the pathogenesis of diseases such as atherosclerosis, neurodegenerative disease, rheumatoid arthritis, age-related degeneration and cancer initiation. These effects of free radicals are through their action on proteins, lipids and DNA. Cells have the innate antioxidant defense system which protects against the dreadful action of free radicals. The superoxide radical scavenging activity of the two test compounds salazinic acid and hexaacetyl salazinic acid were determined at different concentration $(100-500 \mu \mathrm{g} / \mathrm{mL})$. The $\mathrm{IC}_{50}$ values of the test compounds were also determined. The result were given in the Table: 3 . The dose dependent activity of the two test compounds and the standard were expressed in Chart: 5 and Chart: 6. From the result it has been found that the SOD activity of the test samples were dose dependent as the concentration increases the $\%$ inhibition activity also increases and their $\mathrm{IC}_{50}$ values evaluated. $\mathrm{IC}_{50}$ values for the derivative hexaacetyl salazinic acid was less than that of salazinic acid, therefore the derivative of salazinic acid shows higher \% inhibition activity than salazinic acid.

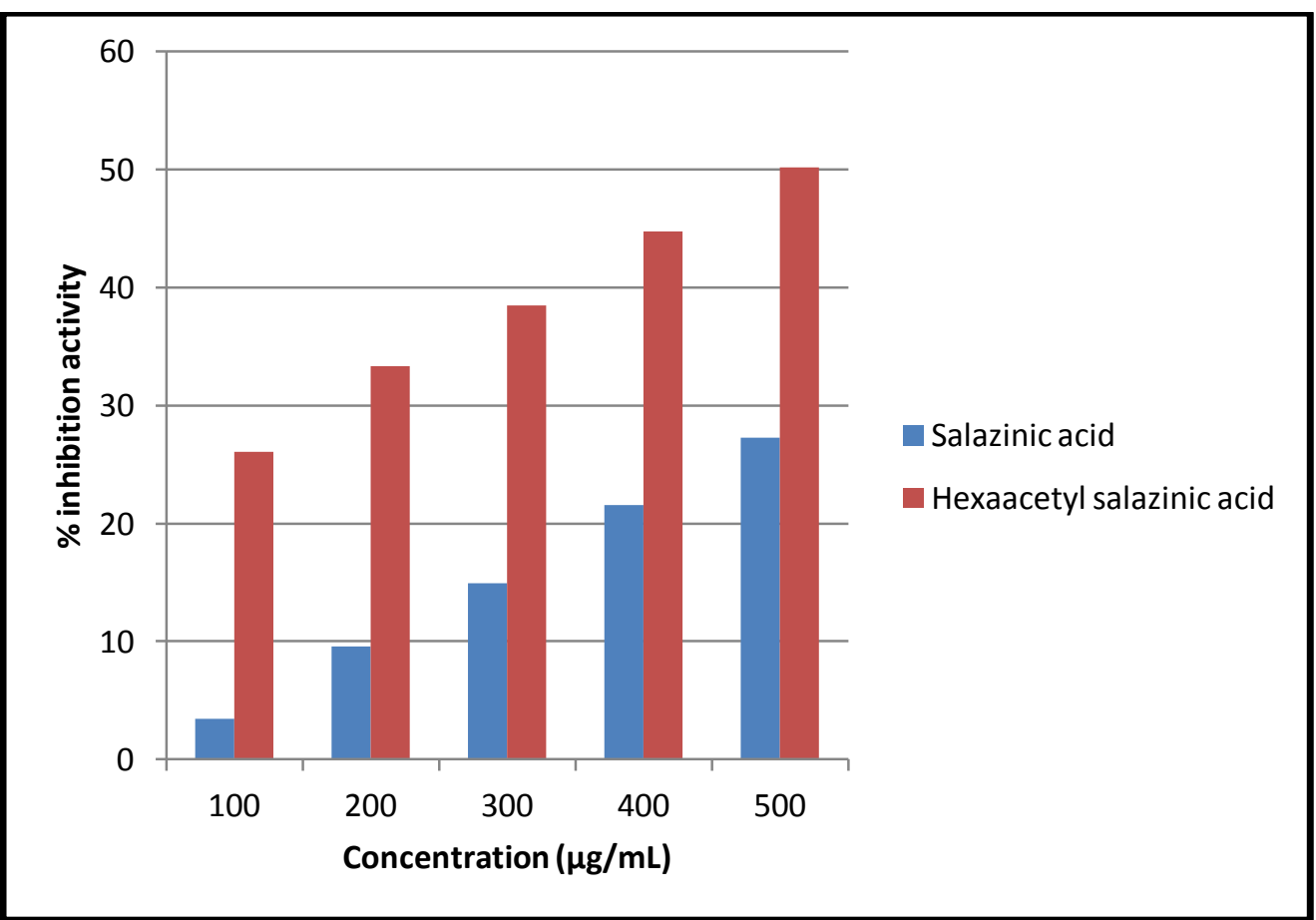

Chart: 5-Superoxide dismutase Scavenging Activity of Salazinic acid and Hexaacetyl salazinic acid 


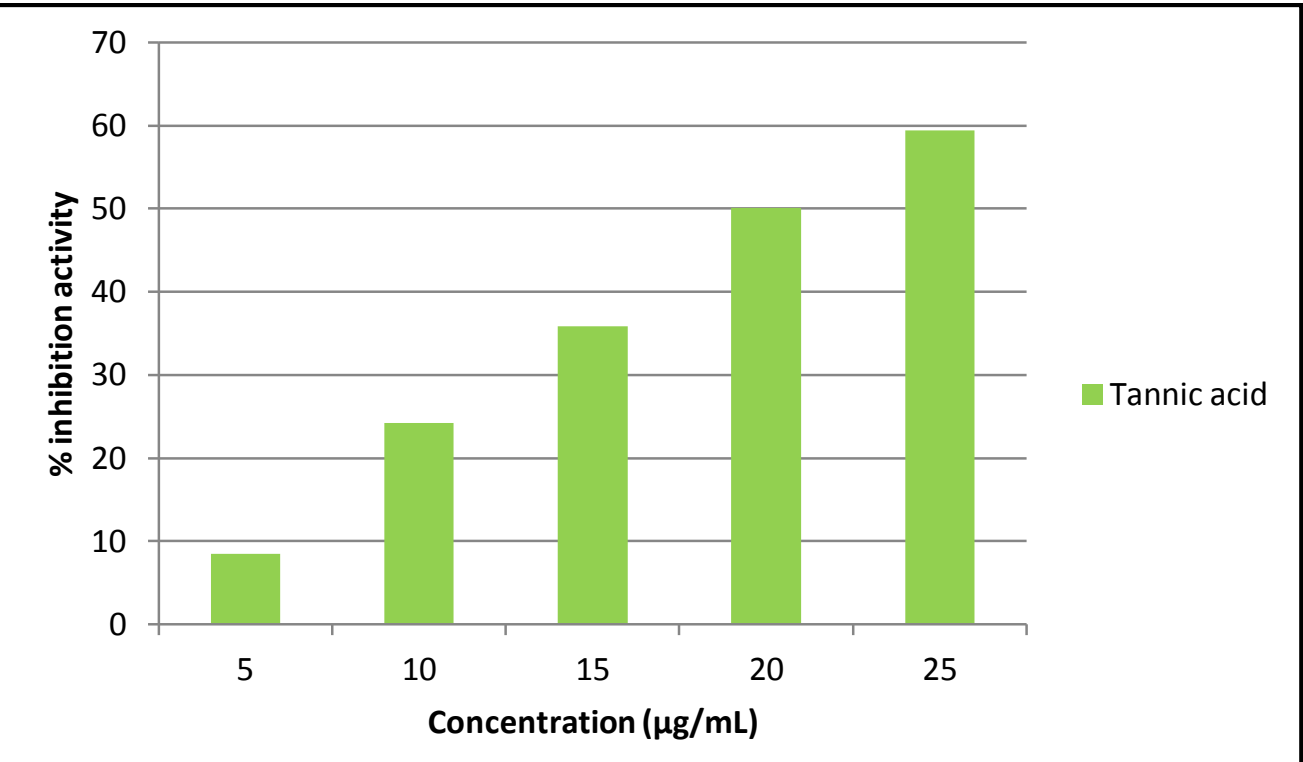

Chart: 6-Superoxide dismutase Scavenging Activity of Tannic acid

Table: 3-Superoxide Dismutase Activity

\begin{tabular}{|l|l|l|l|}
\hline $\begin{array}{l}\text { Test } \\
\text { compound }\end{array}$ & $\begin{array}{l}\text { Concentration } \\
(\mu \mathrm{g} / \mathrm{mL})\end{array}$ & \% Activity & $\mathrm{IC}_{50}(\mu \mathrm{g} / \mathrm{ml})$ \\
\hline & 100 & $3.47 \pm 0.27$ & \\
& 200 & $9.57 \pm 0.81$ & \\
Salazinic & 300 & $14.93 \pm 2.14$ & $294.07 \pm 6.57$ \\
acid & 400 & $21.52 \pm 0.33$ & \\
& 500 & $27.27 \pm 0.13$ & \\
\hline & 100 & $26.09 \pm 1.91$ & \\
Hexaacetyl & 200 & $33.33 \pm 0.60$ & \\
Salazinic & 300 & $38.43 \pm 0.20$ & $133.40 \pm 0.67$ \\
acid & 400 & $44.71 \pm 0.66$ & \\
& 500 & $50.15 \pm 0.42$ & \\
\hline & 5 & $8.54 \pm 0.36$ & \\
Tannic & 10 & $24.24 \pm 0.23$ & \\
acid & 20 & $35.90 \pm 0.23$ & $6.40 \pm 0.05$ \\
& 25 & $50.04 \pm 0.49$ & \\
\hline
\end{tabular}

\subsection{Lipid Peroxidation}

ROS are responsible for the lipid peroxidation in the biological systems. It may be initiate by reactive free radicals by abstracting an allylic hydrogen atom from a methylene group of poly unsaturated fatty acid side chains. Followed by rearrangement of bond. This leads to the stabilization by diene conjugate formation. The Lipid peroxidation inhibiting activity of the two test compounds Salazinic acid and hexaacetyl salazinic acid were determined at different concentration $(100-500 \mu \mathrm{g} / \mathrm{mL})$. The $\mathrm{IC}_{50}$ values of the test compounds were also determined. The result were given in the Table: 4 . The dose dependent activity of the two test compounds and the standard were expressed in Chart: 7. The lipid peroxidation inhibition activity of the test compounds shows higher inhibition activity as the concentration increases. When comparing the two test compounds the lipid peroxidation \% inhibition activity of salazinic acid was better than hexaacetyl salazinic acid. But both the test compound are less active than the standard tannic acid. 


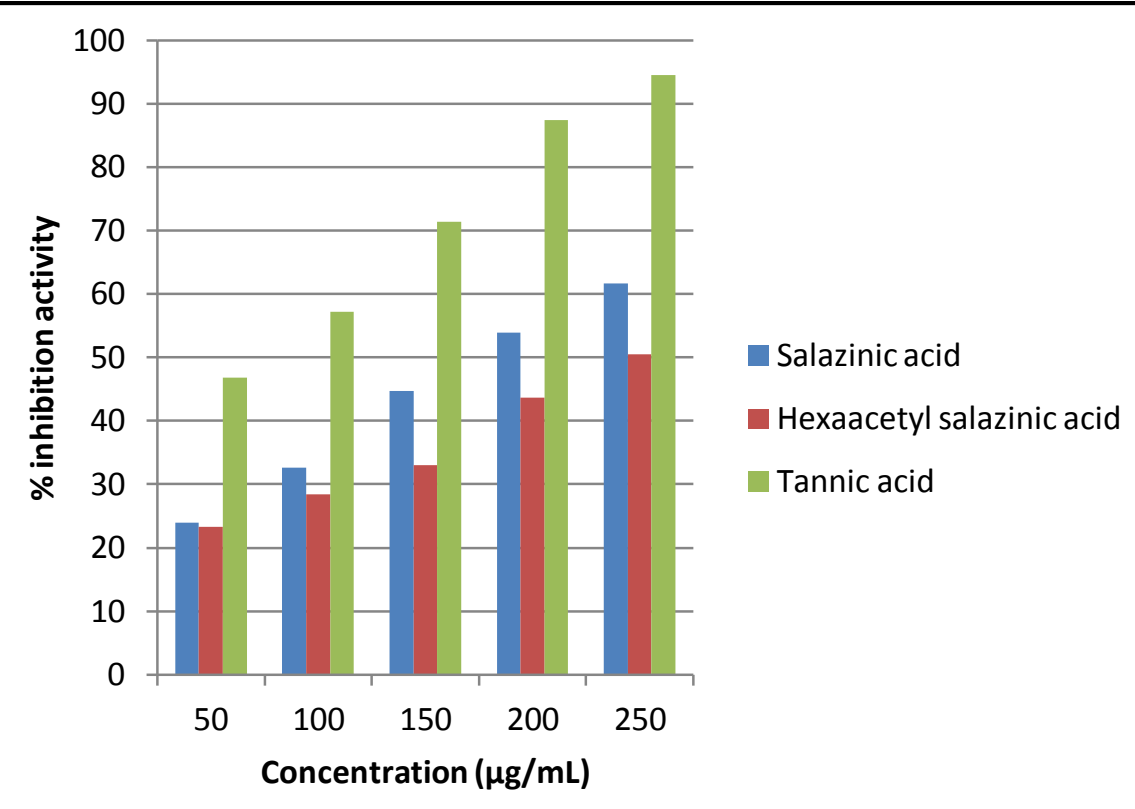

Chart: 7-Lipid Peroxidation Inhibiting Activity of Salazinic acid and Hexaacetylsalazinic acid

Table:4-Lipid Peroxidation Inhibiting Activity

\begin{tabular}{|c|c|c|c|}
\hline $\begin{array}{l}\text { Test } \\
\text { compound }\end{array}$ & $\begin{array}{l}\text { Concentration } \\
(\mu \mathrm{g} / \mathrm{mL})\end{array}$ & $\%$ Activity & $\mathrm{IC}_{50}(\mu \mathrm{g} / \mathrm{ml})$ \\
\hline $\begin{array}{l}\text { Salazinic } \\
\text { acid }\end{array}$ & $\begin{array}{l}50 \\
100 \\
150 \\
200 \\
250\end{array}$ & $\begin{array}{l}23.94 \pm 1.41 \\
32.62 \pm 1.71 \\
44.68 \pm 1.41 \\
53.90 \pm 2.15 \\
61.70 \pm 1.41\end{array}$ & $20.25 \pm 0.04$ \\
\hline $\begin{array}{l}\text { Hexaaacetyl } \\
\text { Salazinic } \\
\text { acid }\end{array}$ & $\begin{array}{l}50 \\
100 \\
150 \\
200 \\
250\end{array}$ & $\begin{array}{l}23.23 \pm 1.11 \\
28.37 \pm 1.34 \\
32.98 \pm 0.92 \\
43.62 \pm 1.60 \\
50.53 \pm 0.53\end{array}$ & $24.98 \pm 0.50$ \\
\hline Tannic acid & $\begin{array}{l}50 \\
100 \\
150 \\
200 \\
250\end{array}$ & $\begin{array}{l}46.77 \pm 0.78 \\
57.14 \pm 1.35 \\
71.43 \pm 2.23 \\
87.41 \pm 2.06 \\
94.56 \pm 1.06\end{array}$ & $13.37 \pm 0.21$ \\
\hline
\end{tabular}

\subsection{Metal Chelating Activity}

Chelating agents can prevent radical generations by chelating the transition metals, because the transition metal ions was responsible for the generation of free radicals. The Metal chelating activity of the two test compounds and standard were given in the Table: 5. The metal chelating activities of the test compounds and the standard were shown in the Chart: 8 . However, the two test sample shows lesser metal chelating activity than the standard tannic acid. Among the test samples derivatives hexaacetyl salazinic acid shown higher activity than the salazinic acid. 
Table: 5-Metal Chelating Activity

\begin{tabular}{|l|l|}
\hline Sample & $\begin{array}{l}\text { Metal chelating activity } \\
\text { (mg EDTA eq./g sample) }\end{array}$ \\
\hline $\begin{array}{l}\text { Salazinic acid } \\
\text { Hexaacetyl Salazinic acid } \\
\text { Tannic acid }\end{array}$ & $6.79 \pm 0.63$ \\
& $18.78 \pm 0.26$ \\
& $126.85 \pm 4.04$ \\
\hline
\end{tabular}

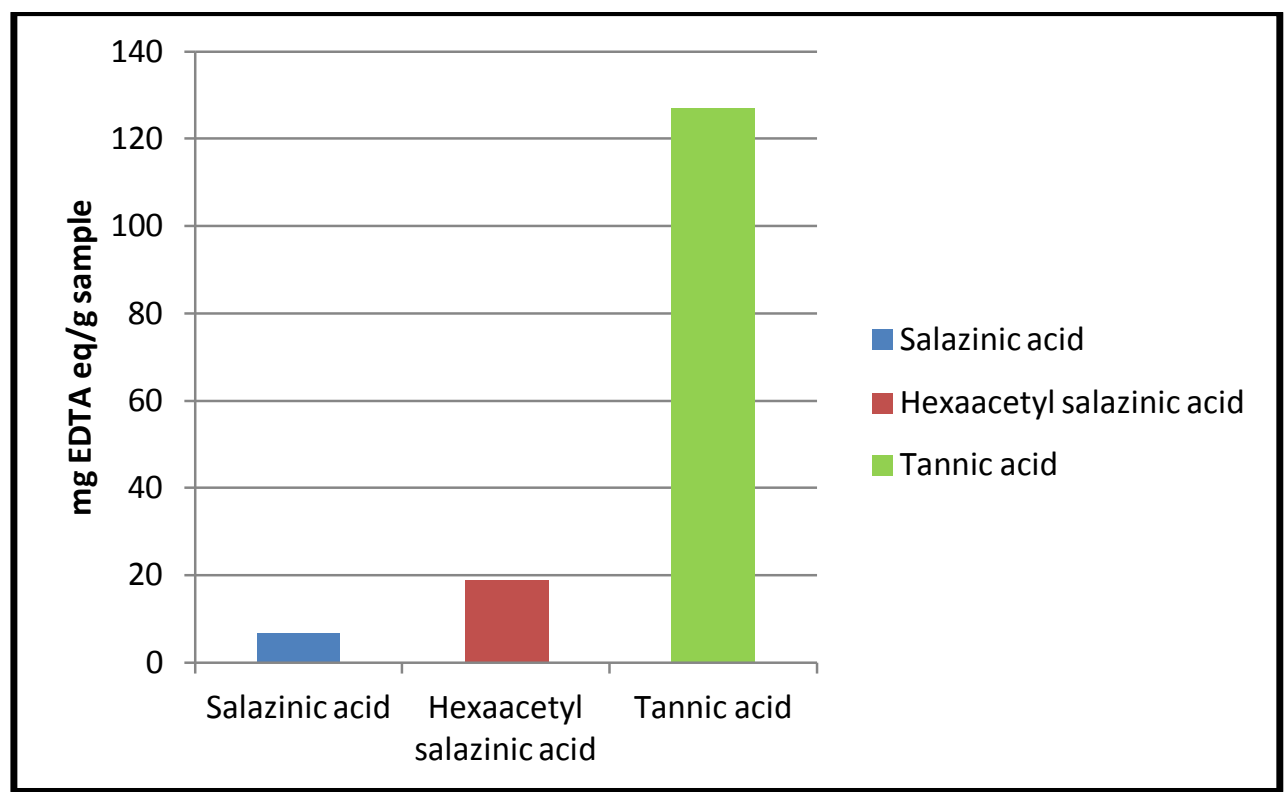

Chart: 8-Metal Chelating Activity of Salazinic acid and Hexaacetyl salazinic acid

\subsection{Phosphomolybdenum Assay}

The Phosphomolybdenum method has been used to investigate the total antioxidant capacity of the pure compound. The total antioxidant capacity of the Salazinic acid and hexaacetyl salazinic acid were assayed by Phosphomolybdenum assay. The Phosphomolybdenum assay of the two test compounds and standard were given in the Table: 6 . The total antioxidant activities of the test compounds and the standard were shown in the Chart: 9. The result shows that the salazinic acid and hexaacetyl salazinic acid both shows lesser total antioxidant activity than the standard Tannic acid. But salazinic acid shows higher total antioxidant activity than that of hexaacetyl salazinic acid.

Table: 6-Phosphomolybdenum assay

\begin{tabular}{|l|l|}
\hline Sample & $\begin{array}{l}\text { Phosphomolydenum } \\
\text { (mg ascorbic acid eq./g } \\
\text { sample) }\end{array}$ \\
\hline Salazinic acid & $117.08 \pm 0.84$ \\
Hexaacetyl Salazinic acid & $85.84 \pm 6.61$ \\
Tannic acid & $187.21 \pm 80.27$ \\
\hline
\end{tabular}




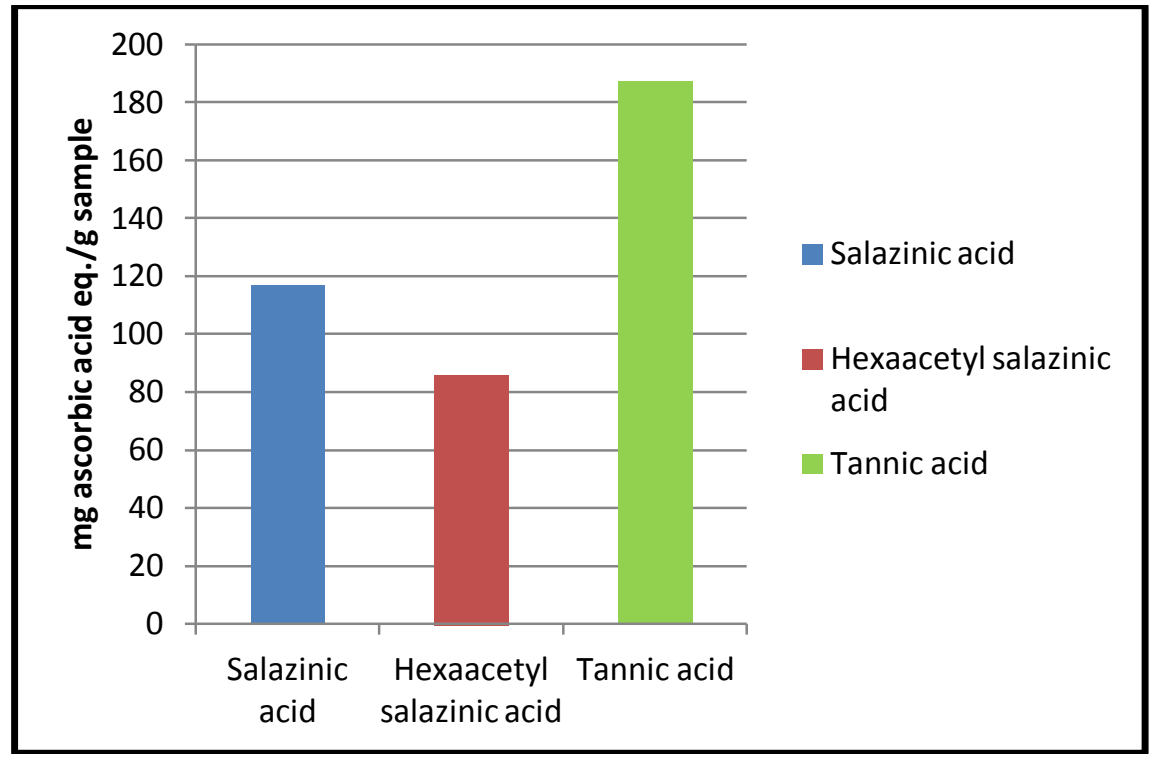

Chart: 9-Phosphomolybdenum activity of salazinic acid, hexaacetylsalazinic acid and Tannic acid

\subsection{Ferric Reducing Antioxidant Power}

FRAP assay is based on the ability of an antioxidant to reduce $\mathrm{Fe}^{3+}$ in the presence of TPTZ, forming an intense blue $\mathrm{Fe}^{2+}$-TPTZ complex with an absorption maximum at $593 \mathrm{~nm}$. The absorbance decrease is proportional to the antioxidant content. The FRAP assay of the two test compounds and standard were given in the Table: 7. The Ferric reducing antioxidant activities of the test compounds and the standard were shown in the Chart: 10. The result shows that among the two test compounds hexaacetyl salazinic acid shows higher activity than salazinic acid, but both the sample less active than the standard tannic acid.

Table: 7-FRAP Assay

\begin{tabular}{|l|l|}
\hline Sample & FRAP $(\mathrm{mmol}(\mathrm{Fe}(\mathrm{II}) / \mathrm{g})$ sample \\
\hline Salazinic acid & $37.18 \pm 7.00$ \\
$\begin{array}{l}\text { Hexaacetyl Salazinic } \\
\text { acid }\end{array}$ & $166.81 \pm 8.44$ \\
Tannic acid & $1335 \pm 160.09$ \\
\hline
\end{tabular}

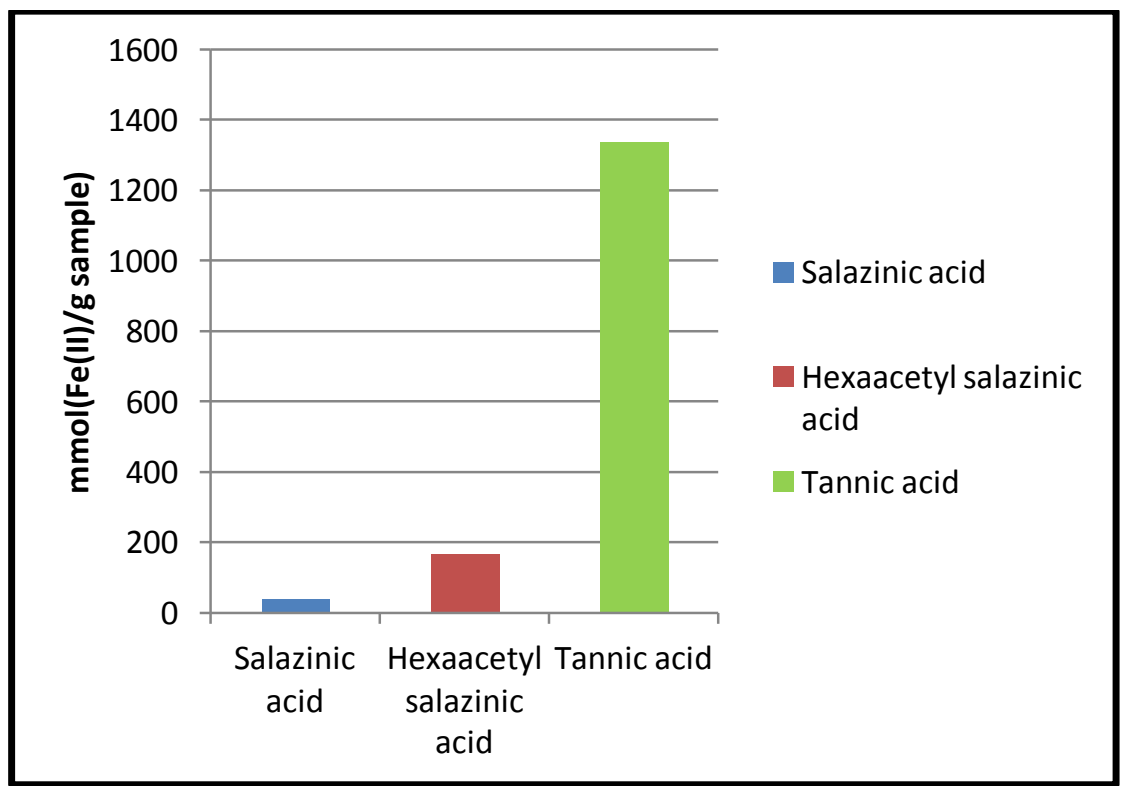

Chart: 10-FRAP activity of salazinic acid, hexaacetyl salazinic acid and Tannic acid 
Table: 8- $\mathrm{IC}_{50}$ value of the test compounds and the standard

\begin{tabular}{|l|l|l|l|}
\hline $\begin{array}{l}\text { Method of } \\
\text { antioxidant } \\
\text { assay }\end{array}$ & $\begin{array}{l}\text { Salazinic } \\
\text { acid } \\
\mathrm{IC}_{50} \text { Value } \\
(\mu \mathrm{g} / \mathrm{mL})\end{array}$ & $\begin{array}{l}\text { Hexaacetyl } \\
\text { salazinic } \\
\text { acid } \\
\mathrm{IC}_{50} \text { Value } \\
(\mu \mathrm{g} / \mathrm{mL})\end{array}$ & $\begin{array}{l}\text { Standard } \\
\text { Tannic acid } \\
\mathrm{IC}_{50} \text { Value } \\
(\mu \mathrm{g} / \mathrm{mL})\end{array}$ \\
\hline $\begin{array}{l}\text { DPPH } \\
\text { Radical } \\
\text { Scavenging }\end{array}$ & $974.66 \pm 30.69$ & $127.78 \pm 2.76$ & $4.31 \pm 0.02$ \\
\hline $\begin{array}{l}\text { Superoxide } \\
\text { Dismutase } \\
\text { activity }\end{array}$ & $294.07 \pm 6.57$ & $133.40 \pm 0.67$ & $6.40 \pm 0.05$ \\
\hline $\begin{array}{l}\text { Hydroxyl } \\
\text { radical } \\
\text { Scavenging }\end{array}$ & $193.36 \pm 0.12$ & $161.87 \pm 1.67$ & $21.51 \pm 0.19$ \\
\hline $\begin{array}{l}\text { Lipid } \\
\text { Peroxidation }\end{array}$ & $20.25 \pm 0.04$ & $24.98 \pm 0.50$ & $13.37 \pm 0.21$ \\
\hline
\end{tabular}

\section{CONCLUSION}

In our present work, we have studied the in-vitro antioxidant activity of salazinic acid and hexaacetyl salazinic acid. But among the two test compounds hexaacetyl salazinic acid gives lower $\mathrm{IC}_{50}$ value and shows higher inhibition activity than salazinic acid for DPPH, Superoxide Distmutase activity, Hydroxyl radical scavenging activity. It was already known that lower the $\mathrm{IC}_{50}$ value higher is the inhibition activity. In lipid peroxidation both the test compounds shows nearly equivalent activity.In Phosphomolybdenum assay salazinic acid shows better activity than hexaacetyl salazinic acid. In FRAP assay hexaacetyl salazinic acid shows better activity than salazinic acid.The metal chelating capacity of both the test compounds were found to be less. From the results, it has been found that the both the test compounds shows lesser activity than the standard Tannic acid. Our test compounds are obtained naturally and are free from side effects.

\section{REFERENCES}

[1] Rosana S.S Barreto, Richardo L.C, AlbuquerqueJunior, Rose NelyPereia-Filho, Jullyana S.S, Quintans, Andre S. Barreto, Josimari M. Desantana, Valter J. Santana-Filho, Marcio R.V. Santos, Leonardo R. Bonjardim, Adriano A.S. Araujo, Lucindo J. Quintans-Junior. "Evaluation of wound healing activity of atranorin, alichen secondary metabolite, on rodents". 2013; Brazilian Journal of Pharmacognosy; 23(2); pp.310-319.

[2] Mohammad Ali Abrahimzadeh, Seyed Mohammad Nabavi, SeyedFazelNabavi, FathemehBahramian and Ahmad Reza Bekhradnia. "Antioxidant and free radical scavenging activity of $\mathrm{H}$. Officinalis L. Var. Angustifolius, V. Odorata, B. Hyrcana and C.Speciosum". 2010; Pak. J. Pharm. Sci; 23(1); pp.29-34.

[3] IlhamiGulcin, ZubeyrHuyut, MahfuzElmastas, Hassan Y. Aboul-Enein. Radical Scavenging and antioxidant activity of tannic acid. Arabian Journal of Chemistry 2010; 3, pp.43-53.
[4] Blois MS. Antioxidant determinations by the use of a stable free radical. Nature. 1958; 26: pp.11991200.

[5] Klein SM, Cohen G and Cederbaum AI. Production of formaldehyde during metabolism of dimethyl sulphoxide by hydroxyl radical generating system. Biochem. 1991; 20: pp.6006-6012.

[6] Beauchamp C and Fridovich I. Superoxide dismutase: Improved assays and an assay applicable to acrylamide gels. Anal. Biochem. 1971; 44: pp.276-277.

[7] Benzie IFF, Strain JJ. The ferric reducing ability of plasma (FRAP) as a measure of "Antioxidant power". The FRAP assay. Anal Biochem. 1996; 239: pp.70-76.

[8] Dinis TCP, Maderia VMC and Almeidia MCM. Action of phenolic derivatives (acetoaminophen, Salycilate and 5-amino salycilate) as inhibitors of membrane lipid peroxidation and as peroxyl radical scavenger. Arch. Biochem. Biophys. 1994; 315: pp.161-169.

[9] Prieto P, Pineda $\mathrm{M}$ and Aguilar $\mathrm{M}$. Spectrophotometric quantitation of antioxidant capacity through the formation of a phosphomolybdenum complex: specific application to the determination of vitamin E. Anal Biochem. 1999; 269: pp.337-341.

[10] Ohkawa, H., Ohishi, N., Yagi, K. Assay forlipid peroxides in animal tissues by thiobarbituric acid reaction. Analytical Biochemistry, 1979; 95: pp.351358. 